\title{
PENGEMBANGAN KEWIRAUSAHAAN BAGI UP2K-PKK KELURAHAN PRAWIRODIRJAN GONDOMANAN YOGYAKARTA UNTUK MENDUKUNG PEMASARAN PRODUK MENGGUNAKAN INSTAGRAM
}

\author{
Salam Aryanto ${ }^{1}$, Sudaryanto ${ }^{2}$, Haruno Sajati ${ }^{3}$, \\ Anggraini Kusumaningrum ${ }^{4}$, Dwi Nugraheny ${ }^{5}$, Hero Wintolo 6 \\ $\mathbf{1 , 2 , 3 , 4 , 5 , \mathbf { 6 }}$ Program Studi Teknik Informatika \\ Sekolah Tinggi Teknologi Adisutjipto \\ J1. Janti, Blok R, Lanud Adisutjipto Yogyakarta \\ Email: ${ }^{1}$ salamaryanto@stta.ac.id, ${ }^{2}$ sudaryanto@stta.ac.id, ${ }_{3}^{3}$ harunosajati@stta.ac.id, \\ ${ }^{4}$ anggraini@stta.ac.id, ${ }^{5}$ henynug@stta.ac.id, ${ }^{6}$ herowintolo@stta.ac.id
}

\begin{abstract}
Community service is focused on woman for PKK Family Income Improvement (UP2K PKK) which is one of the poverty reduction programs aimed at women in Prawirodirjan Village Gondomanan District Yogyakarta Municipality Special Province of Yogyakarta. Problems faced by mothers Efforts to Increase PKK Family Income (UP2K PKK) include innovating both products, packaging and network marketing. From the results of training and mentoring, $75 \%$ or 21 community service participants had good skills in product marketing techniques, and of the 21 participants as many as $14 \%$ were very active in conducting broadcasts through Instagram.
\end{abstract}

Keywords: UP2K PKK, Instagram, Product Marketing.

\begin{abstract}
Abstrak
Pengabdian pada masyarakat ini difokuskan pada ibu-ibu guna Upaya Peningkatan Pendapatan Keluarga PKK (UP2K PKK) yang merupakan salah satu program penanggulangan kemiskinan dengan sasarannya kaum perempuan di Kelurahan Prawirodirjan Kecamatan Gondomanan Kotamadya Yogyakarta Propinsi Daerah Istimewa Yogyakarta. Permasalahan yang dihadapi oleh ibu-ibu Upaya Peningkatan Pendapatan Keluarga PKK (UP2K PKK) diantaranya adalah melakukan inovasi baik produk, kemasan dan jaringan pemasaran. Dari hasil pelatihan dan pendampingan, $75 \%$ atau 21 peserta pengabdian masyarakat memiliki kemampuan yang baik dalam teknik pemasaran produknya, dan dari 21 peserta tersebut sebanyak $14 \%$ sangat aktif dalam melakukan pemsaran melalui instagram.
\end{abstract}

Kata Kunci: UP2K PKK, Instagram, Pemasaran Produk.

\section{Latar Belakang}

Salah satu tugas dosen dalam Tri Dharma Perguruan Tinggi adalah melaksanakan kegiatan pengabdian pada masyarakat. Bentuk dari pengabdian pada masyarakat dapat berupa kemitraan masyarakat, kemitraan masyarakat stimulus, kuliah kerja nyata pembelajaran dan pemberdayaan masyarakat, pengembangan kewirausahaan, produk 
unggulan daerah, pengembangan usaha produk intelektual kampus, pengembangan desa mitra, kemitraan wilayah, pemeberdayaan masyarakat unggulan perguruan tinggi dan penerapan iptek kepada masyarakat[1]. Pengabdian pada masyarakat yang dilakukan sebelumnya mengambil obyek pengabdian yaitu guru dan murid dari Sekolah Dasar Islam Terpadu (SDIT) Salsabila Al Muthi'in untuk berbagi pengetahuan dalam bidang multimedia dan animasi untuk meningkatkan kualitas pemebelajaran[2][3][4][5]. Kemampuan pengelolaan data multimedia ini dapat digunakan sebagai pembuatan profil produk yang nantinya menunjang pemasaran.

Pada kegiatan pengabdian pada masyarakat yang kami sampaikan disini menggunakan obyek ibu-ibu dari Upaya Peningkatan Pendapatan Keluarga PKK (UP2K PKK) merupakan salah satu program penanggulangan kemiskinan yang sasarannya kaum perempuan di Kelurahan Prawirodirjan Kecamatan Gondomanan Kotamadya Yogyakarta Propinsi Daerah Istimewa Yogyakarta. UP2K PKK memiliki peran penting dalam kehidupan keluarga di Indonesia, hal ini disebabkan adanya penambahan nilai ekonomis keluarga dari kegiatan yang ada pada UP2K PKK. Permasalahan yang dihadapi dan melakukan upaya-upaya pengembangan usaha, antara lain : (a) memberi masukan dan pembinaan untuk perbaikan kualitas, penampilan dan kemasan produk kue kering; (b) mengadakan penyuluhan mengenai pengembangan dan inovasi produk maupun kemasan; (c) memberi penyuluhan dalam membangun jaringan pemasaran dan kemitraan; dan (d) membantu anggota kelompok untuk melakukan inovasi baik produk, kemasan dan jaringan pemasaran[6]. Bentuk pengabdian yang dilakukan dalam bentuk pendampingan untuk mendukung pemasaran produk menggunakan media sosial instagram.

Media sosial instagram dapat digunakan untuk menampilkan atau posting dalam bentuk gambar (foto) dan tulisan. Dengan menampilkan foto tempat[7], toko[8], produk[9], barang[10], kegiatan social[11] dan produk industri kreatif[12] di instagram dapat memberikan dampak terhadap pengikut akun instagram, pembeli dan pendatang yang terpengaruh secara positif pada tampilan foto tersebut. Harapan dari kegiatan yang dilakukan di instagram ini, produk dari UP2K PKK akan dikenal dan diminati hingga dibeli oleh masyarakat pada tingkat lokal, regional dan internasional.

\section{Masalah}

Ada dua permasalahan yang dihadapi oleh UP2K PKK Kelurahan Prawirodirjan yang diselesaikan dengan melakukan pendampingan, yaitu :

1. Kurangnya kemampuan pelaku UP2K-PKK Prawirodirjan dalam memasaran produk, permasalahan ini diselesaikan dengan pendampingan pemanfaatan Instagram untuk pemasaran produk yang dihasilkan.

2. Terbatasnya informasi tentang pemilihan metode pemasaran dalam penyampaian pesan oleh pelaku UP2K-PKK Prawirodirjan untuk meningkatkan brand awarness dan brand recognition, permasalahan ini diselesaikan dengan pelatihan pemasaran produk menggunakan Instagram sebagai strategi peningkatan pemasaran dan penjualan produk.

\section{Metode Pelaksanaan Pengabdian}

Metode Pelaksanaan Pengabdian pada Masyarakat ini meliputi beberapa komponen yaitu:

1. Sumber Daya Manusia (SDM)

Metode yang digunakan untuk memenuhi kebutuhan SDM dengan melakukan pelatihan dan pendampingan pemasaran produk bagi pelaku UP2K PKK kelurahan Prawirodirjan menggunakan sosial media Instagram. 
2. Proses

Pendampingan oleh pelaksana pengabdian masyarakat kepada pelaku UP2KPKK Prawirodirjan diawali dengan sosialisasi pengenalan internet dan pembuatan akun e-mail ataupun akun Instagram untuk pemasaran produk dan pengenalan Instagram, kemudian dilanjutkan dengan pendampingan dalam menyiapkan kebutuhan data multimedia serta dilanjutkan dengan pengarahan penggunakan Instagram secara maksimal untuk pemasaran produk.

3. Produk

Menghasilkan pelaku UP2K-PKK Prawirodirjan yang mampu memanfaatkan Instagram untuk pemasaran produk.

4. Manajemen

Setelah melakukan sosialisasi, dilanjutkan dengan memberikan pendampingan pelaku UP2K-PKK Prawirodirjan untuk dilatih dalam memanfaatkan akun e-mail ataupun akun Instagram untuk pemasaran produk melalui Instagram secara efektif.

\section{Hasil dan Pembahasan}

Hasil luaran yang dicapai dari kegiatan pengabdian kepada masyarakat antara lain:

1. Adanya bahan ajar (modul), tentang pembuatan akun e-mail ataupun akun Instagram dan teknik pemasaran produk melalui media Instagram untuk pelaku UP2K-PKK Prawirodirjan.. Adapun jumlah pelaku UP2K-PKK Prawirodirjan yang mengikuti pelatihan dan pendampingan sejumlah 28 peserta. Modul tersebut berisi tentang pembuatan akun e-mail ataupun akun Instagram serta langkah-langkah teknik pemasaran produk melalui media Instagram.

2. Melatih ibu-ibu pelaku UP2K-PKK Prawirodirjan untuk memahami manfaat teknologi melalui smartphone dan aplikasi instagram guna meningkatkan pemasaran produk yang selama ini mereka hasilkan.

Adapun hasil pemahaman dan keaktifan ibu-ibu UP2K-PKK Prawirodirjan dalam pemasaran produk-produk mereka melalui media Instagram diantaranya disajikan pada gambar 1 ( $a$ dan b), gambar 2 ( $a$ dan b). 


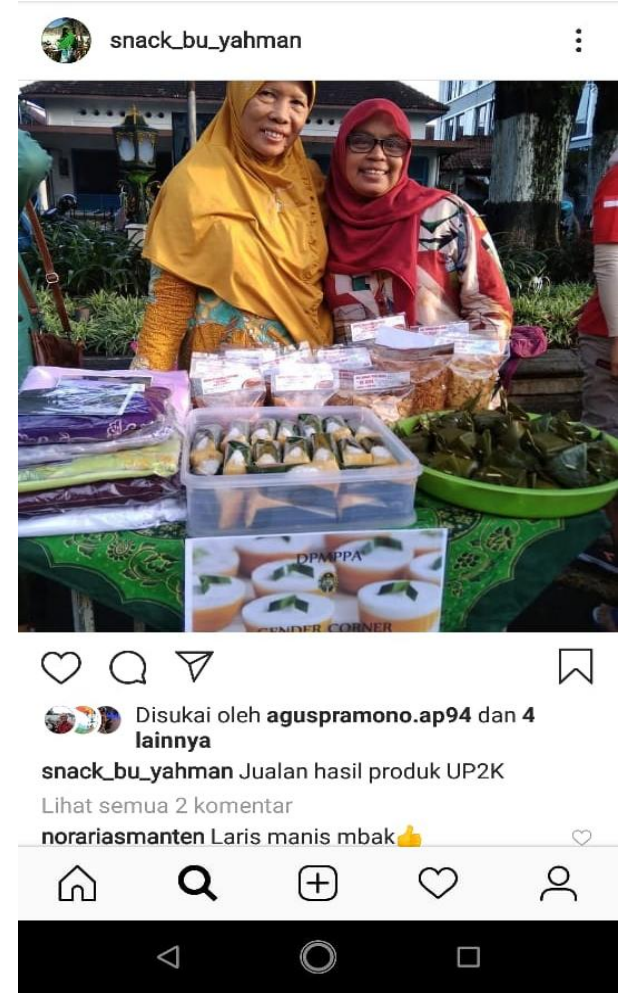

(a)

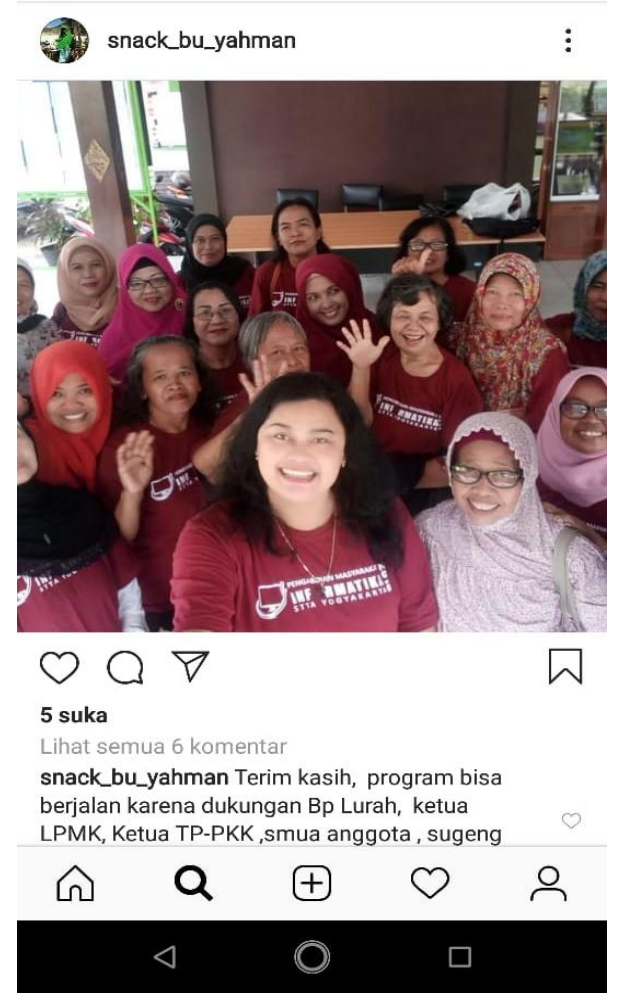

(b)

Gambar 1. (a) dan (b) Hasil pemasaran produk snack bu Yahman melalui Instagram

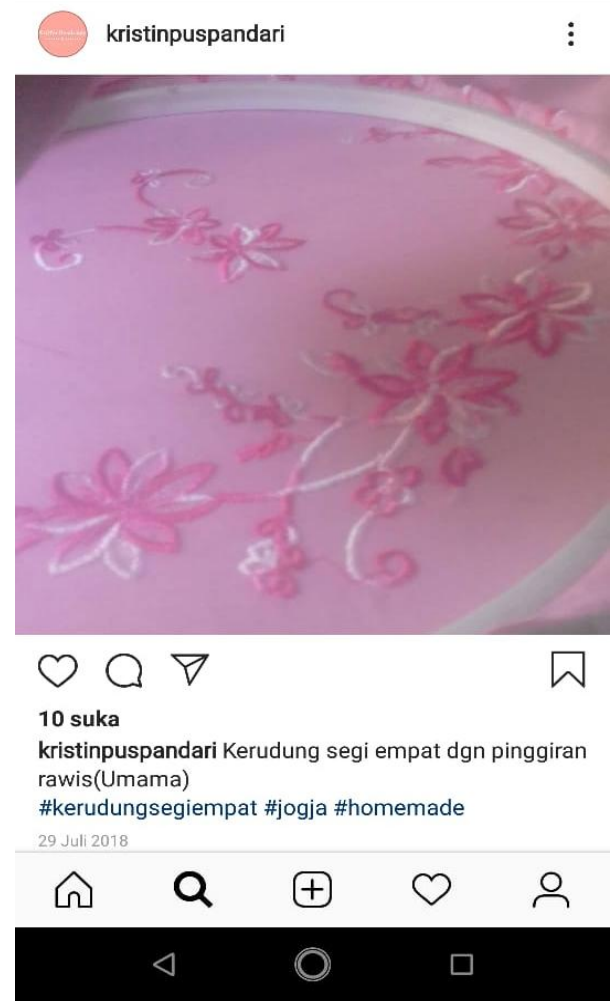

(a)

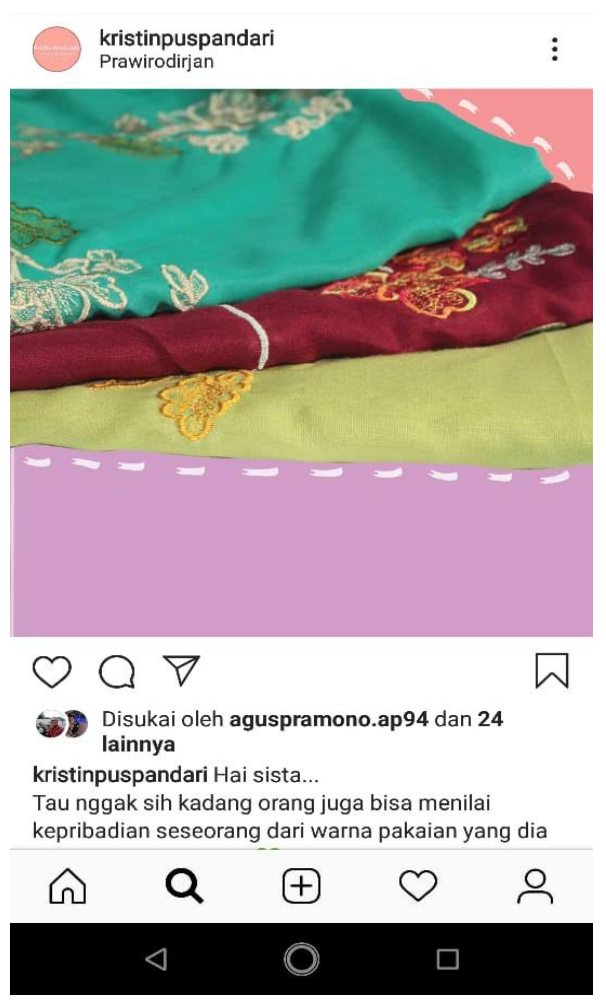

(b)

Gambar 2. (a) dan (b) Hasil pemasaran produk kerudung bordir Kristin Puspadari melalui Instagram. 
Gambar 3 merupakan suasana ibu-ibu UP2K-PKK Prawirodirjan saat mengikuti pelatihan tentang pembuatan akun e-mail ataupun akun Instagram serta langkahlangkah teknik pemasaran produk melalui media Instagram.
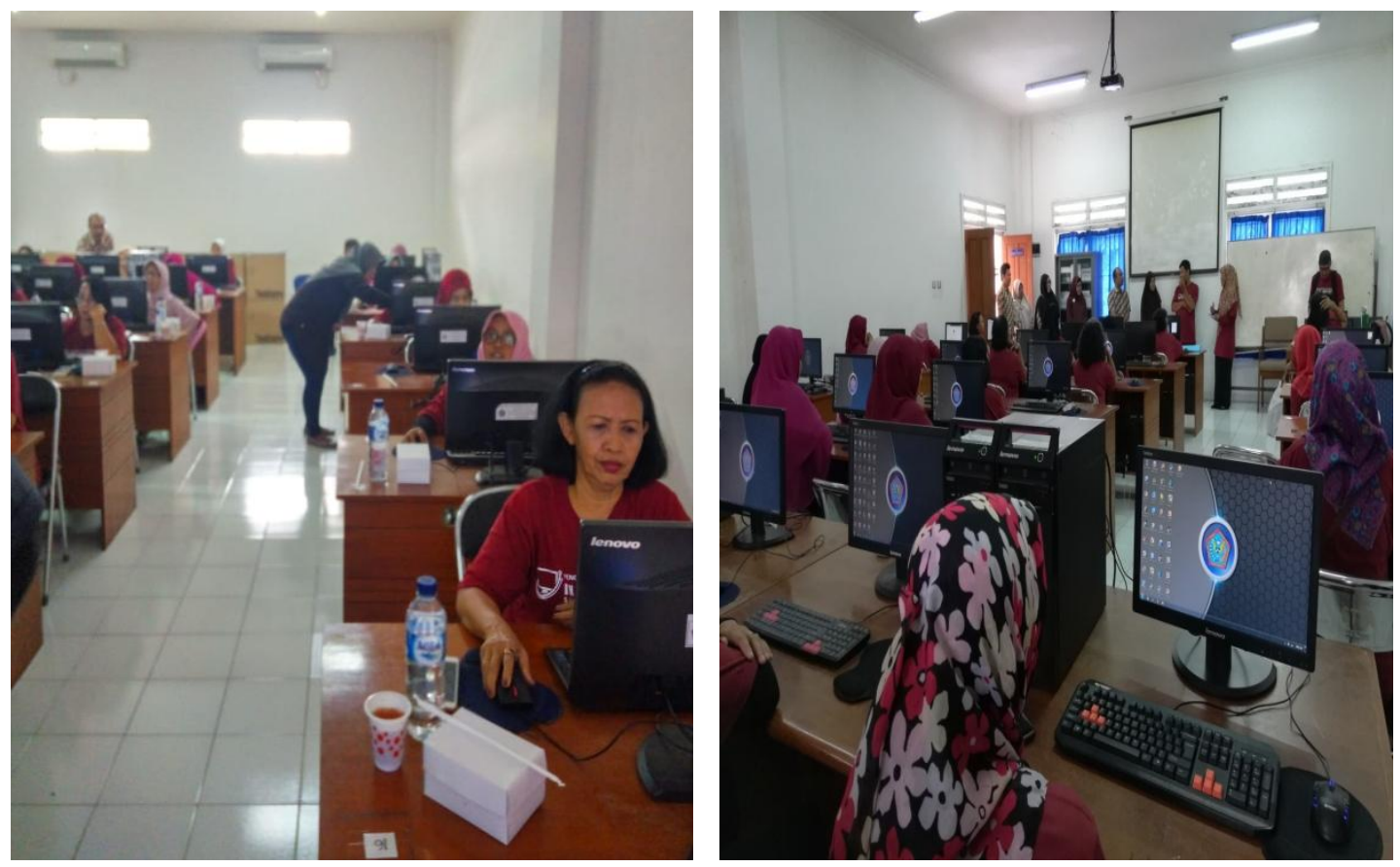

Gambar 3. Suasana ibu-ibu UP2K-PKK Prawirodirjan saat mengikuti pelatihan dan pendampingan pemasaran produk melalui Instagram.

Tabel 1 menunjukkan hasil pelatihan dan pendampingan ibu-ibu pelaku UP2K-PKK Prawirodirjan yang telah paham dengan baik, cukup bahkan kurang akan materi pelatihan yang diberikan dari pembuatan akun e-mail, mengambil gambar-gambar produk serta meng-uploadnya. Tabel 1 juga menunjukkan hasil keaktifan ibu-ibu dalam pemasaran produk melalui Instagram.

Tabel 1. Hasil pelatihan dan pendampingan ibu-ibu pelaku UP2K-PKK Prawirodirjan

\begin{tabular}{|c|c|c|c|c|c|}
\hline \multirow[t]{2}{*}{$\begin{array}{c}\text { Nama pelaku UP2K-PKK } \\
\text { Prawirodirjan }\end{array}$} & \multicolumn{3}{|c|}{$\begin{array}{c}\text { Teknik Pemasaran } \\
\text { produk }\end{array}$} & \multicolumn{2}{|c|}{$\begin{array}{c}\text { Keaktifan Pemasaran } \\
\text { dengan Instagram }\end{array}$} \\
\hline & Baik & Cukup & Kurang & Ya & Kurang \\
\hline Bpk. Rusdi Haryanto & $\sqrt{ }$ & & & & $\sqrt{ }$ \\
\hline Bpk. Ajar Permono & $\sqrt{ }$ & & & & $\sqrt{ }$ \\
\hline Ibu Sri Lestari & $\sqrt{ }$ & & & & $\sqrt{ }$ \\
\hline Ibu Isti Faijah & $\sqrt{ }$ & & & & $\sqrt{ }$ \\
\hline Ibu Kuswati & & $\sqrt{ }$ & & & $\sqrt{ }$ \\
\hline Ibu Baridjatin S. & $\sqrt{ }$ & & & & $\sqrt{ }$ \\
\hline Ibu Issrimaryatun & & $\sqrt{ }$ & & & $\sqrt{ }$ \\
\hline Ibu Hermi Indrawati & $\sqrt{ }$ & & & & $\sqrt{ }$ \\
\hline
\end{tabular}


Ibu Siti Partiwi

Ibu Herniwati

Ibu C. Sumiyati

Ibu Endang Banowati

Ibu Eny Purwatiningsih

Ibu Sri Ningsih

Ibu Th. Gesang Sri A.

Ibu N. Subagyo

Ibu Erna Supartinah

Ibu Susi Parwati

Ibu Sumaryati

Ibu Agustin

Ibu Betharinawati

Ibu Sutini

Ibu Budi Artini

Ibu Ria Kartini

Ibu Sumaryati

Ibu Rahayu Mulyo S.

Ibu Tri Mulyani

Ibu Kristin Puspadari

\section{Kesimpulan}

Berdasarkan hasil pelatihan dan pendampingan pengembangan kewirausahaan bagi UP2K-PKK Kelurahan Prawirodirjan Gondomanan Yogyakarta untuk mendukung pemasaran produk menggunakan Instagram diperoleh kesimpulan sebagai berikut:

1. Dari hasil pelatihan dan pendampingan, $75 \%$ atau 21 peserta pengabdian masyarakat memiliki kemampuan yang baik dalam teknik pemasaran produknya, dan dari 21 peserta tersebut sebanyak 14\% sangat aktif dalam melakukan pemsaran melalui instagram.

2. Instagram merupakan salah satu media berpromosi atau pemasaran produk yang sangat efektif.

3. Melalui pelatihan dan pendampingan ini, ibu-ibu UP2K-PKK Kelurahan Prawirodirjan Gondomanan Yogyakarta sangat antusias dalam mengikuti tahap-tahap teknik pemasaran dengan Instagram.

4. Sebaiknya pelaku UP2K-PKK Kelurahan Prawirodirjan Gondomanan Yogyakarta aktif dalam mempromosikan atau memasarkan produk melalui media Instagram agar penjualan produk dikenal banyak orang, diminati hingga dibeli oleh masyarakat pada tingkat lokal, regional dan internasional. 


\section{Daftar Pustaka}

[1] Jawab, P., \& Penyusun, T. Panduan Penelitian Dan Pengabdian Kepada Masyarakat Edisi XII Tahun 2018.

[2] Ayuningtyas, A., Honggowibowo, A. S., Pujiastuti, A., Retnowati, N. D., \& Indrianingsih, Y. (2018). Pendampingan Pembuatan Bahan Ajar Bagi Guru Sekolah Dasar Islam Terpadu (SDIT) Salsabila Al Muthi'in Berbasis Multimedia dengan Menggunakan Microsoft Power Point. KACANEGARA Jurnal Pengabdian pada Masyarakat, 1(1), 1-6.

[3] Nugraheny, D., Wintolo, H., \& Kusumaningrum, A. (2018). Pendampingan Pembuatan Bahan Ajar Berbasis Multimedia Menggunakan Macromedia Flash Bagi Para Guru SD IT Salsabila Al Muthi' in, Yogyakarta. KACANEGARA Jurnal Pengabdian pada Masyarakat, 1(1), 23-28.

[4] Ayuningtyas, A., Retnowati, N. D., Pujiastuti, A., Indrianingsih, Y., \& Honggowibowo, A. S. (2019). Pelatihan Mendesain Artikel Artistik Menggunakan Microsoft Word Bagi Kelas 5 SD di SDIT Salsabila Al Muthi'in Yogyakarta. KACANEGARA Jurnal Pengabdian pada Masyarakat, 2(1), 13-20.

[5] Nugraheny, D., Wintolo, H., Kusumaningrum, A., Sudaryanto, S., \& Sajati, H. (2019). Pendampingan Pengenalan Metode Pengetikan Cepat Menggunakan Microsoft Word Bagi Siswa Kelas 5 SD IT Salsabila Al Muthi'in Yogyakarta. KACANEGARA Jurnal Pengabdian pada Masyarakat, 2(1), 21-28.

[6] Indarto, A. S. (2018). Penguatan Usaha Melalui Perluasan Jaringan Pemaaran dan Inovasi Produk Kue Kering dan Snak pada Kelompok UP2K Kelurahan Gisikdrono, Kecamatan Semarang Barat, Kota Semarang. Jurnal DIANMAS, $7(3)$.

[7] Indika, D. R., \& Jovita, C. (2017). Media sosial instagram sebagai sarana promosi untuk meningkatkan minat beli konsumen. Jurnal Bisnis Terapan, 1(01), 25-32.

[8] Lestari, D. P. (2015). Analisis strategi internet marketing butik online di Surabaya melalui instagram. Commonline Departemen Komunikasi, 4(2), 412424.

[9] Arief, G. M., \& Millanyani, H. (2015). Pengaruh Social Media Marketing Melalui Instagram Terhadap Minat Beli Konsumen Sugar Tribe. eProceedings of Management, 2(3).

[10] Andini, N. P. (2014). Pengaruh viral marketing terhadap kepercayaan pelanggan dan keputusan pembelian (Studi Pada Mahasiswa Fakultas Ilmu Administrasi Universitas Brawijaya Angkatan 2013 yang Melakukan Pembelian Online Melalui Media Sosial Instagram). Jurnal Administrasi Bisnis, 11(1).

[11] Zulfikar, A. R., \& Mikhriani, M. (2017). Pengaruh social media marketing terhadap brand trust pada followers instagram dompet dhuafa cabang yogyakarta. Al-Idarah: Jurnal Manajemen Dan Administrasi Islam, 1(2), 279-294.

[12] Gumilar, G. (2016). Pemanfaatan instagram sebagai sarana promosi oleh pengelola industri kreatif fashion di kota Bandung. JIPSI-Jurnal Ilmu Politik dan Komunikasi UNIKOM, 5(2). 
Salam Aryanto, Sudaryanto, Haruno Sajati, Anggraini Kusumaningrum, Dwi Nugraheny, Hero Wintolo 